\title{
Pengaruh Pendekatan CTL Berbantuan Satua Bali Terhadap Kompetensi Sikap Sosial
}

\author{
*Kadek Puspasari ${ }^{1}$, I Ketut Ardana², Made Putra ${ }^{3}$ \\ ${ }^{123}$ Pendidikan Guru Sekolah Dasar, Universitas Pendidikan Ganesha, Singaraja, Indonesia
}

\author{
A R T I C L E I N F O \\ Article history: \\ Received 15 August 2019 \\ Received in revised form \\ 20 September 2019 \\ Accepted 10 October 2019 \\ Available online 29 \\ November 2019 \\ Kata Kunci: \\ sikap sosial, CTL, satua Bali \\ Keywords: \\ social attitude, CTL, Balinese \\ story
}

\begin{abstract}
A B S T R A K
Berkurangnya sikap sosial anak diakibatkan dengan adanya perkembangan teknologi menjadi masalah yang tidak bisa diabaikan. Penelitian ini bertujuan untuk mengetahui pengaruh pendekatan CTL berbantuan satua Bali terhadap kompetensi sikap sosial siswa kelas III SDN. Penelitian ini menggunakan desain eksperimen semu dengan bentuk Non-equivalent post test only control group design. Populasi penelitian ini adalah seluruh siswa kelas III SD yang terdiri dari 14 kelas dengan jumlah 492 siswa. Sample penelitian ini mengunakan teknik random sampling, yang memperoleh sampel sebnayak 71 orang. Data kompetensi sikap sosial siswa diperoleh melalui instrumen berupa kuesioner berjumlah 30 butir yang telah divalidasi. Data yang diperoleh dianalisis menggunakan uji-t dengan rumus polled varians. Berdasarkan hasil analisis dengan uji $t$, diperoleh harga thitung $=4,024>t_{\text {tabel }} 2,000$ dengan taraf signifikan $5 \%$ dan $\mathrm{dk}=69$, maka terdapat perbedaan yang
\end{abstract} signifikan kompetensi sikap sosial antara kelompok eksperimen dan kelompok kontrol. Dengan demikian dapat disimpulkan bahwa pendekatan CTL berbantuan satua Bali memiliki pengaruh yang signifikan terhadap kompetensi sikap sosial siswa kelas III SDN.

\begin{abstract}
A B S T R A C T
The lack of childrens' social attitudes due to technological development become a problem that could not be ignored. This research aims to determine the effect of the CTL approach assisted by Balinese story on the social attitude's competency on third grade students. This research used a quasiexperimental design with non-equivalent post-test only control group design. The population of this research was 14 groups on third grade students of elementary school totaled 492 students. Both groups were selected by random sampling technique. Determination of the experimental and control groups was carried out by lottery method to obtain on third grade students in elementary School with 38 students as the experimental group and class IIIA with 33 students as the control group. Competency data of students' social attitudes obtained through the instrument in the form of a questionnaire totalled 30 items that had been validated. The data obtained were analyzed by using the $t$-test with the polled variance formula. Based on the results of the analysis with the $t$ test, the score of $t$-count $=4.024>t$-table 2,000 with a significant level of $5 \%$ and $d k=69$, then there was a significant difference in the competency of social attitudes between the experimental group and the control group. Thus, it could be concluded that the CTL approach assisted by Balinese story had a significant effect on the competency of the social attitudes on third grade students of elementary school.
\end{abstract}

\section{Pendahuluan}

Sekolah Dasar sebagai salah satu lembaga formal dasar yang bernaung di bawah Kementerian Pendidikan Nasional, mengemban misi dasar dalam memberikan kontribusi untuk mencapai tujuan pendidikan nasional. Implementasi di Sekolah Dasar untuk mencapai tujuan pendidikan nasional yakni melalui pembelajaran. Untuk mengukur pencapaian tujuan pendidikan nasional, pada Sekolah Dasar diimplementasikan melalui penilaian hasil belajar. Dalam Permendikbud Nomor 23 Tahun 2016 tentang standar penilaian dinyatakan bahwa, "penilaian hasil belajar peserta didik pada pendidikan dasar meliputi

Copyright (c) Universitas Pendidikan Ganesha. All rights reserved. 
aspek sikap, pengetahuan, dan keterampilan". Sejalan dengan hal tersebut, dalam Permendikbud Nomor 24 tahun 2016, dinyatakan bahwa dalam kurikulum 2013 terdapat kompetensi inti yang merupakan tingkat pencapaian standar kompetensi kelulusan yang harus dimiliki seorang peserta didik pada setiap tingkat kelas. Kompetensi inti yang dimaksud terdiri atas kompetensi inti sikap spiritual, kompetensi inti sikap sosial, kompetensi inti pengetahuan, dan kompetensi inti keterampilan. Jadi, acuan penilaian hasil belajar peserta didik dimuat dalam kompetensi inti yang telah mencakup aspek-aspek hasil belajar.

Berkaitan dengan penilaian hasil belajar khususnya aspek sikap, dalam UU Sistem Pendidikan Nasional No. 20 Tahun 2003 tertuang tujuan pendidikan nasional, yaitu "untuk berkembangnya potensi peserta didik agar menjadi manusia yang beriman dan bertaqwa kepada Tuhan Yang Maha Esa, berkahlak mulia, sehat, berilmu, cakap, kreatif, mandiri, dan menjadi warga Negara yang demokratis, serta bertanggung jawab". Rumusan tujuan pendidikan tersebut berkaitan dengan pembentukan sikap yang dapat dinilai melalui kompetensi inti sikap sosial.

Kompetensi merupakan perpaduan dari pengetahuan, keterampilan, nilai dan sikap yang direfleksikan dalam kebiasaan berpikir dan bertindak (Sanjaya, 2010). Sedangkan menurut (Yusuf, 2015) kompetensi merupakan perpaduan skill, tingkah laku dan pengetahuan serta nilai-nilai dasar yang dapat didemonstrasikan atau direfleksikan dalam kebiasaan serta kemampuan berpikir dan bertindak siswa yang dicapai melalui kegiatan mengajar yang bermakna dan penuh arti. (Christin Septina Basani, 2015)Kompetensi yang harus dikuasai peserta didik dinyatakan sedemikian rupa agar dapat dinilai. Jadi, dapat dirangkum bahwa kompetensi merupakan perpaduan antara aspek pengetahuan, keterampilan, sikap dan tingkah laku yang dapat direfleksikan dalam kebiasaan berpikir dan dicapai siswa melalui kegiatan pembelajaran.

Sikap dikatakan sebagai suatu respons evaluatif. Respon hanya akan timbul apabila individu dihadapkan pada suatu stimulus yang menghendaki adanya reaksi individual. Terbentuknya suatu sikap dipengaruhi oleh lingkungan sosial dan kebudayaan(Nurlaela, 2016). Sikap sebagai suatu kesadaran individu dalam melakukan perbuatan pada kegiatan sosial. Menurut Ahmadi (2009:149), sikap adalah kesadaran individu yang menentukan perbuatan nyata dalam kegiatan-kegiatan sosial". Seseorang dalam bersikap kepada orang lain akan membentuk sikap sosial. Hal tersebut dikarenakan sikap sosial akan menimbulkan interaksi atau komunikasi dengan orang lain sehingga seseorang dapat saling bekerja sama. Sejalan dengan pendapat dari (Abu Ahmadi, 2009), menyatakan bahwa sikap sosial adalah kesadaran individu yang menentukan perbuatan nyata secara berulang-ulang terhadap objek sosial". Objek sosial yang dimaksud ialah pada kehidupan masyarakat.

Berdasarkan pemaparan tersebut, kompetensi sikap sosial adalah perwujudan kesadaran individu yang direfleksikan dalam perbuatan nyata terhadap objek sosial melalui kegiatan pembelajaran, sehingga menimbulkan interaksi sosial. Menurut Walgito (2003:135), faktor-faktor yang menyebabkan perubahan sikap yakni faktor internal dan faktor eksternal. Faktor internal berupa selectivity atau daya pilih seseorang untuk menerima dan mengolah pengaruh-pengaruh yang datang dari luar. Faktor eksternal berupa hal-hal atau keadaan yang ada di luas individu yang merupakan stimulus untuk membentuk atau mengubah sikap. Menurut (Sanjaya, 2010), terdapat dua proses dalam pembentukan sikap yaitu pembiasaan dan modeling.

Pada jenjang Sekolah Dasar, kompetensi sikap sosial merupakan salah satu kompetensi yang tercantum dalam KI-2 Kurikulum 2013. Adapun aspek-aspek yang mengacu pada KI-2 yaitu jujur, disiplin, tanggung jawab, peduli (toleransi, gotong royong), santun, percaya diri. Aspek-aspek sikap sosial tersebut dapat dijadikan acuan dalam pembuatan instrumen penelitian untuk mengetahui sikap sosial yang dimiliki siswa. Berdasarkan tujuan pendidikan nasional, maka diharapkan pembelajaran di Sekolah Dasar lebih memperhatikan aspek sikap sosial. Karena pada jenjang pendidikan Sekolah Dasar merupakan pondasi yang kuat untuk membentuk karakter anak. Hal ini sejalan dengan Sedanayasa (2015) yang menyatakan bahwa, pada periode Sekolah Dasar merupakan saat-saat yang baik untuk membentuk sikapsikap dasar anak terhadap kelompok sosial dan lembaga sosial. Untuk itu proses pembelajaran perlu memperhatikan aspek sikap khususnya sikap sosial, agar nantinya siswa memiliki karakter yang baik sesuai dengan tujuan pendidikan nasional.

Penerapan kurikulum 2013 pada tingkat Sekolah Dasar, menggunakan tematik terpadu yang merupakan salah satu upaya pemerintah dalam mengoptimalkan kurikulum 2013 agar kompetensi inti dapat tercapai terutama kompetensi inti sikap sosial. Tercapainya kompetensi inti sikap sosial ditandai dengan ciri dari tematik terpadu yakni, terdapat kegiatan pembelajaran yang menuntut siswa untuk aktif (student center) dan berinteraksi dalam kelompok belajar. Dengan demikian, melalui pembelajaran tematik terpadu siswa dapat mengembangkan aspek sikap sosial. Berdasarkan observasi dan wawancara yang dilakukan pada tanggal 13 November 2018 sampai dengan 16 November 2018. Diperoleh informasi bahwa pada kenyataannya kurang terlaksana secara optimal. Hal tersebut dapat terlihat dari. 1) Sikap siswa pada saat proses pembelajaran kurang mencerminkan karakter yang baik sesuai dengan tujuan 
pendidikan nasional, 2) Kurang optimalnya penggunaan alat penunjang pembelajaran sederhana, 3) Kurangnya respon dan kemampuan siswa dalam memecahkan masalah pada proses pembelajaran, dan 4) Inovasi penggunaan pendekatan pembelajaran yang kurang optimal.

Implementasi yang kurang baik dari sikap sosial siswa, terlihat ketika siswa fokus berbicara dengan temannya pada saat guru sedang menjelaskan materi, siswa cenderung kurang bersosialisasi pada saat pembentukan kelompok, serta beberapa siswa terlihat malu bahkan menolak ketika diminta untuk menjawab pertanyaan pada saat pembelajaran. Dengan demikian, sikap sosial yang tertanam pada diri siswa perlu ditingkatkan. Selain itu, dalam proses pembelajaran guru telah mengoptimalkan penggunaan sarana dan prasarana seperti penggunaan LCD (Liquid Crystal Display). Namun, sarana dan prasarana yang terdapat disekolah jumlahnya terbatas, hal tersebut mengakibatkan guru mengalami kendala dalam menyampaikan materi pelajaran yang berkaitan dengan sikap sosial. Dalam proses pembelajaran, mayoritas guru menggunakan alat penunjang pembelajaran yang modern seperti penggunaan $L C D$. Sesuai dengan hasil observasi di SDN Gugus Kolonel I Gusti Ngurah Rai, terlihat budaya bercerita dalam penyampaian nasehat maupun materi pelajaran kian ditinggalkan. Terlihat di dalam kelas guru jarang memanfaatkan alat penunjang pembelajaran sederhana namun menarik, seperti bercerita atau penggunaan satua sebagai media pembelajaran yang bervariasi. Dalam meningkatkan sikap sosial siswa yang masih rendah, diperlukan kreativitas dan inovasi dalam proses pembelajaran yaitu dengan menerapkan pendekatan $C T L$ berbantuan satua Bali pada proses pembelajaran.

Menurut Rusman (2015:186), pendekatan dapat diartikan sebagai titik tolak atau sudut pandang terhadap proses pembelajaran. Pendekatan dapat diartikan sebagai titik tolak atau sudut pandang kita terhadap proses pembelajaran. Istilah pendekatan merujuk kepada pandangan tentang terjadinya suatu proses yang sifatnya masih sangat umum, (Abdullah, 2017) Pendekatan merupakan langkah awal pembentukan suatu ide dalam memandang suatu masalah atau objek kajian.

Pendekatan CTL adalah pendekatan pembelajaran yang mengaitkan antara materi pelajaran dengan situasi dunia nyata sehingga terdapat interaksi sosial antar siswa, guru dan lingkungan. Pendekatan CTL memiliki tujuh komponen pembelajaran yaitu konstruktivisme, inkuiri, bertanya, masyarakat belajar, pemodelan, refleksi, dan penilaian autentik.

Trianto (2015) menyatakan bahwa pendekatan CTL berbeda dengan pendekatan lainnya, sehingga memiliki karakteristik khusus yakni, kerja sama, saling menunjang, menyenangkan (joyfull), tidak membosankan (comfortable), belajar dengan bergairah, pembelajaran terintegrasi, memakai berbagai sumber, siswa aktif. Selain itu, (Hidayatin, 2016) menyatakan, "pendekatan kontekstual memberikan arti dan manfaat khususnya bagi siswa diantaranya, dapat meningkatkan motivasi belajar siswa dalam memecahkan masalah serta mendapat pengalaman belajar yang dapat digunakan untuk menyelesaikan permasalahan".

Adapun kelebihan dari pendekatan CTL menurut (Sanjaya, 2010) yaitu pembelajaran CTL menekankan kepada proses keterlibatan siswa secara penuh untuk menemukan materi yang dipelajari dan menghubungkan dalam kehidupan sehari-hari, pembelajaran di dalam kelas dapat berlangsung secara alamiah, alam pembelajaran CTL siswa dapat belajar melalui kegiatan kelompok, pembelajaran dikaitkan dengan kehidupan nyata, dalam pembelajaran CTL kemampuan didasarkan atas pengalaman, dalam pembelajaran CTL tindakan atau perilaku dibangun atas kesadaran diri sendiri, dalam pembelajaran $C T L$ pengetahuan yang dimiliki setiap individu selalu berkembang sesuai dengan pengalaman yang dialaminya, tujuan akhir dari proses CTL adalah kepuasan diri.

Agar pembelajaran menjadi lebih menarik, maka pendekatan CTL dipadukan dengan menggunakan bantuan satua Bali. Dalam budaya masyarakat di Bali, untuk menyampaikan nasehat biasanya disampaikan melalui bersatua. Pada saat ini budaya bercerita (mesatua) kian ditinggalkan, padahal mesatua memilki manfaat tersendiri bagi anak-anak khususnya dalam pembentukan sikap sosial.

(Sadirman, 2014), menyatakan media adalah segala sesuatu yang dapat digunakan untuk menyalurkan pesan dari pengirim ke penerima sehingga dapat merangsang pikiran, perasaan, perhatian, dan minat siswa sedemikian rupa sehingga proses belajar terjadi. Sedangkan (Sanjaya, 2010)menyatakan bahwa, "media bukan hanya berupa alat atau bahan saja, akan tetapi hal-hal yang memungkinkan siswa dapat memperoleh pengetahuan." Jadi dapat dirangkum bahwa, media bukan hanya berupa alat atau bahan saja, akan tetapi hal-hal yang memungkinkan siswa dapat memperoleh pengetahuan yang digunakan untuk menyalurkan pesan dalam mencapai tujuan pembelajaran.

Pada penelitian ini menggunakan satua Bali sebagai media pembelajaran. Satua dalam bahasa Indonesia dikenal dengan cerita. Bercerita merupakan salah satu contoh komunikasi yang efektif untuk mengubah sikap, karena unsur-unsur sikap dapat diselipkan dalam bersatua. Merubah atau membentuk sikap dilakukan juga oleh salah satu ahli yaitu Skinner dalam teorinya operant conditioning. Teori tersebut menekankan pada proses peneguhan respon anak. (I Gusti Kade Budi Astawa, Putu Nanci Riastini, 2016), menyatakan, satua Bali memiliki nilai budaya, nilai karakter, dan amanat sehingga pembelajaran yang 
berlangsung menjadi lebih menarik, menyenangkan, dan bermanfaat bagi pengembangan sikap sosial siswa. Selain itu, (A.A.Istri Vera Mahayuni, Nym. Kusmariyatni, 2015)berpendapat bahwa, manfaat cerita bagi anak adalah membantu pembentukan pribadi dan moral anak, menyalurkan kebutuhan imajinasi dan fantasi, memacu kemampuan verbal anak, merangsang minat menulis anak, merangsang minat baca anak, dan membuka cakrawala pengetahuan anak. Tradisi bercerita dalam budaya kehidupan masyarakat di Bali banyak digunakan untuk menyampaikan nasehat atau saran tentang perilaku khususnya dikalangan anak-anak (Wirata, 2016). Bercerita dapat dilakukan dimana saja, dan Sekolah Dasar dianggap sebagai tempat yang paling tepat untuk melestarikan tradisi mesatua. Penggunaan satua Bali dapat dilakukan oleh guru atau meilbatkan siswa. Guru memilih satua yang dianggap cocok dengan materi pelajaran, kemudian disesuaikan dengan kondisi dan lingkungan siswa. Dalam hal ini, isi cerita hendaknya tentang sekitar pengalaman kehidupan nyata dari siswa sehingga mudah dimengerti dan dipahami.

Berdasarkan uraian yang telah dipaparkan, dapat dirangkum bahwa pendekatan CTL berbantuan satua Bali adalah pendekatan pembelajaran yang dibantu dengan satua Bali, dengan mengaitkan antara materi pelajaran dan situasi dunia nyata siswa sehingga terdapat interaksi sosial antar siswa, guru dan lingkungan. Berdasarkan uraian tersebut, maka dilaksanakan penelitian untuk mengetahui pengaruh pendekatan CTL berbantuan satua Bali dalam upaya meningkatkan kompetensi sikap sosial siswa. Dengan demikian, dilaksanakanlah Penelitian yang bertujuan untuk mengetahui pengaruh pendekatan CTL berbantuan satua Bali terhadap kompetensi sikap sosial siswa kelas III SDN.

\section{Metode}

Penelitian ini merupakan penelitian kuantitatif yaitu menggunakan desain ekperimen semu (quasi experiment design). Hal ini dikarenakan tidak semua variabel yang muncul dalam eksperimen dapat diatur dan dikontrol secara ketat. Bentuk desain yang digunakan dalam penelitian ini adalah non-equivalent post test only control group design. Desain penelitian dapat dilihat pada tabel 1.

Tabel 1. Desain Penelitian

\begin{tabular}{lll}
\hline Kelompok & Perlakuan & Kuesioner setelah perlakuan \\
\hline Eksperimen & $\mathrm{X}_{1}$ & $\mathrm{O}_{1}$ \\
\hline Kontrol & $\mathrm{X}_{2}$ & $\mathrm{O}_{2}$ \\
\hline
\end{tabular}

(Sumber: (Agung, 2014))

Keterangan:

X1 : perlakuan pembelajaran dengan pendekatan CTL berbantuan satua Bali pada kelompok eksperimen

X2 : dibelajarkan pembelajaran tanpa pendekatan CTL berbantuan satua Bali pada kelompok kontrol

01 : Kuesioner setelah perlakuan pada kelompok eksperimen

02 : Kuesioner setelah perlakuan pada kelompok kontrol

Rancangan penelitian ini melibatkan dua kelompok yaitu kelompok eksperimen dan kelompok kontrol. Dua kelompok yang terlibat diberikan perlakuan yaitu dengan menerapkan pendekatan CTL berbantuan satua Bali kepada kelompok eksperimen dan menerapkan pembelajaran tanpa pendekatan CTL berbantuan satua Bali kepada kelompok kontrol. Setelah diberikan perlakuan, diberikan kuesioner untuk mengetahui kompetensi sikap sosial siswa. Prosedur yang akan dilaksanakan dalam penelitian ini terdiri dari tiga tahapan yaitu, tahap persiapan, tahap pelaksanaan, dan tahap akhir eksperimen.

Penelitian ini dilaksanakan di kelas III SDN Gugus Kolonel I Gusti Ngurah Rai Kecamatan Denpasar Utara terdiri dari 6 Sekolah Dasar Negeri yang dilaksanakan mulai bulan Januari 2019 hingga bulan Mei 2019. Perlakuan pada kelompok eksperimen dan pembelajaran pada kelompok kontrol diberikan sebanyak 8 kali pertemuan dengan jam pelajaran yang disesuaikan dengan materi yang telah diatur berdasarkan kurikulum.

(Wahyuni et al., 2016)menyatakan "populasi merupakan kelompok yang lebih besar jumlahnya dan biasanya yang dipakai untuk mengeneralisasi hasil penelitian". Jadi populasi adalah keseluruhan objek atau subjek yang memiliki kualitas dan karakteristik tertentu yang ditentukan peneliti, kemudian dilakukan penelitian dan ditarik kesimpulan sehingga dapat dipakai untuk mengeneralisasi hasil penelitian. Populasi penelitian ini adalah seluruh siswa kelas III SDN Gugus Kolonel I Gusti Ngurah Rai Kecamatan Denpasar Utara tahun pelajaran 2018/2019 yang terdiri dari 14 kelas dengan jumlah 492 siswa. 
Banyaknya anggota dalam populasi menyebabkan tidak memungkinkan untuk meneliti semua objek yang ada, sehingga digunakan sampel yang diambil dari populasi untuk menentukan kelas eksperimen dan kelas kontrol. Sampel merupakan bagian atau kelompok kecil dari jumlah dan karakteristik yang dimiliki populasi dan diambil dengan teknik tertentu. Sampel penelitian merupakan faktor penting yang mencerminkan dan menentukan seberapa jauh sampel dapat bermanfaat dalam membuat kesimpulan penelitian. Teknik pengambilan sampel pada penelitian ini yaitu random sampling. Penentuan sampel dilakukan dengan cara pengundian. Pengundian dilakukan agar semua anggota populasi memiliki kesempatan yang sama untuk dipilih menjadi sampel penelitian dan memenuhi syarat representatif. Setelah dilakukan pengundian, diperoleh hasil dua kelompok yang terpilih sebagai sampel penelitian yaitu kelas III A di SD Negeri 6 Ubung dan kelas III C di SD Negeri 1 Ubung.

Kedua kelompok yang terpilih sebagai sampel, kemudian diambil data sikap sosial yang telah dimiliki sekolah. Data sikap sosial yang diperoleh, kemudian dianalisis menggunakan uji t untuk memperoleh kelas yang setara. Setelah dianalisis dan kedua kelompok dinyatakan setara, maka dilakukan pengundian untuk menentukan kelompok eksperimen dan kelompok kontrol. Berdasarkan hasil pengundian, diperoleh kelas III C SD Negeri 1 Ubung sebagai kelompok eksperimen dan kelas III A SD Negeri 6 Ubung sebagai kelompok kontrol.

Pada penelitian ini data yang dikaji adalah data kuesioner kompetensi sikap sosial siswa. Data tersebut diperoleh dengan menggunakan metode non test dalam bentuk kuesioner yang berisi 30 butir pernyataan. Pernyataan tersebut terdiri dari pernyataan negatif dan positif. Penyusunan instrumen sikap sosial berpedoman pada kisi-kisi kuesioner yang telah disusun berdasarkan kompetensi yang akan dicapai. Selain itu, instrumen tersebut dilakukan uji validitas agar diperoleh gambaran kelayakan dari untuk digunakan dalam penelitian. Uji validitas instrumen yang dilakukan yaitu uji validitas konstruk, uji validitas butir, uji reliabilitas. Jumlah butir pernyataan pada kuesioner sebelum diuji yakni 35 butir. Setelah itu dilaksanakan uji validitas konstruk yang dibantu dengan melibatkan pakar/ahli (judgesment expertise). Kemudian dilaksanakan uji validitas butir dengan teknik korelasi product moment. Uji validitas butir dihitung dengan bantuan program Microsoft Office Excel 2010. Berdasarkan uji validitas butir yang telah dilakukan, terdapat 30 pernyataan yang valid. Selanjutnya, dilakukan uji reliabilitas yang dihitung pada kuesioner hanya untuk butir-butir yang tidak gugur (valid). Dalam penelitian ini untuk menentukan reliabilitas digunakan rumus Koefision Alpha Cronbach yang secara khusus dipergunakan untuk menghitung reliabilitas tes data politomi. Uji reliabilitas dihitung dengan bantuan program Microsoft Office Excel 2010. Berdasarkan penghitungan terhadap 30 butir pernyataan yang valid diperoleh Koefision Alpha Cronbach sebesar 0,872. Dilihat dari indeks koefisien reliabilitas, maka koefisien reliabilitas tersebut tingkat hubungannya sangat tinggi.

Setelah memperoleh data kuesioner kompetensi sikap sosial siswa, maka dilaksanakan analisis data yaitu analisis statistik inferensial yang digunakan untuk melakukan analisis data sampel dengan menguji hipotesis. Pada penelitian ini uji hipotesis menggunakan uji t. Teknik analisis tersebut terlebih dahulu dilakukan uji prasyarat analisis yaitu uji normalitas sebaran data dan uji homogenitas varians. Uji normalitas sebaran data yang digunakan pada penelitian ini menggunakan Kolmogorov-Smirnov. Kriteria pada uji normalitas Kolmogorov-Smirnov adalah signifikansi uji pada nilai | Ft - Fs | terbesar dibandingkan nilai tabel kolmogorov smirnov. Pada taraf signifikansi 5\%, dan perbandingan jumlah siswa, apabila nilai | Ft - Fs | terbesar kurang dari nilai tabel kolmogorov smirnov, maka Ho ditolak dan Ha diterima. Uji homogenitas varians untuk kedua kelompok digunakan uji F. Dengan kriteria pengujian pada taraf signifikansi $5 \%$ derajat kebebasan untuk pembilang $n_{1}-1$ dan derajat kebebasan untuk penyebut $n_{2}-1$. Jika harga $F_{\text {hitung }} \leq F_{t a b e l}$ maka sampel homogen.

Data yang telah memenuhi uji prasyarat uji normalitas dan uji homogenitas, dilanjutkan dengan pengujian hipotesis. Adapun hipotesis statistik yang diujikan yaitu $\mathrm{H}_{0}=$ tidak terdapat perbedaan yang signifikan kompetensi sikap sosial antara kelompok siswa yang mengikuti pembelajaran dengan menerapkan pendekatan CTL berbantuan satua Bali dan kelompok siswa yang mengikuti pembelajaran dengan menerapkan pembelajaran konvensional pada kelas III SDN Gugus Kolonel I Gusti Ngurah Rai Kecamatan Denpasar Utara Tahun Pelajaran 2018/2019. Krieria pengujian ini dengan taraf signifikansi $5 \%$ dengan $\mathrm{dk}=\mathrm{n}_{1}+\mathrm{n}_{2}-2$, jika harga $\mathrm{t}_{\text {hitung }} \geq \mathrm{t}_{\text {tabel }}$ maka $\mathrm{H}_{\mathrm{o}}$ ditolak dan $\mathrm{H}_{\mathrm{a}}$ diterima. Adapun rumus uji $\mathrm{t}$ yang digunakan dengan rumus polled varians sebagai berikut.

$$
t=\frac{\overline{X_{1}}-\overline{X_{2}}}{\sqrt{\frac{\left(n_{1}-1\right) s_{1}{ }^{2}+\left(n_{2}-1\right) s_{2}{ }^{2}}{n_{1}+n_{2}-2}\left(\frac{1}{n_{1}}+\frac{1}{n_{2}}\right)}}
$$




\section{Hasil dan Pembahasan}

Data penelitian yang diperoleh adalah data hasil kuesioner kompetensi sikap sosial kelompok eksperimen dan kelompok kontrol. Data hasil kuesioner kompetensi sikap sosial kelompok eksperimen Tabel 2.

Tabel 2. Data Hasil Post Test Kelompok Eksperimen

\begin{tabular}{lcc}
\hline Statistik & Data & Kelompok Eksperimen \\
\hline Nilai Minimum & 105 \\
Nilai Maksimum & 120 \\
Rata-rata & 112,74 \\
Variansi & 25,44 \\
Standar Deviasi & 5,04 \\
\hline
\end{tabular}

Berdasarkan Tabel 2 diperoleh perolehan data hasil kuesioner pada kelompok eksperimen yaitu rata-rata hitung sebesar 107,48, nilai maksimum sebesar 118, nilai minimum sebesar 100, standar deviasi sebesr 5,97 dan variansi sebesar 35,70. Sedangkan Data hasil kuesioner kompetensi sikap sosial kelompok kontrol dapat dilihat pada Tabel 3

Tabel 3. Data Hasil Kuesioner Kelompok Kontrol

\begin{tabular}{lc}
\hline \multicolumn{1}{c}{ Data } & Kelompok Kontrol \\
\hline Statistik & 100 \\
\hline Nilai Minimum & 118 \\
Nilai Maksimum & 107,48 \\
Rata-rata & 35,70 \\
Variansi & 5,97 \\
Standar Deviasi & \\
\hline
\end{tabular}

Berdasarkan Tabel 3 diperoleh perolehan data hasil kuesioner pada kelompok kontrol yaitu rata-rata hitung sebesar 107,48, nilai maksimum sebesar 118, nilai minimum sebesar 100, standar deviasi sebesr 5,97 dan variansi sebesar 35,70.

Kategori variabel kompetensi sikap sosial dapat diketahui dengan cara rata-rata hitung dikonversikan ke dalam kategori skala lima menggunakan kriteria rata-rata ideal $\left(\mathrm{M}_{\mathrm{i}}\right)$ dan standar deviasi ideal $\left(\mathrm{SD}_{\mathrm{i}}\right)$ disajikan pada Tabel 4.

Tabel 4. Kategori Data Kompetensi Sikap Sosial

\begin{tabular}{cc}
\hline Rentang skor & Kategori \\
$97,5 \leq \bar{X} \leq 120$ & Sangat tinggi \\
$82,5 \leq \bar{X}<97,5$ & Tinggi \\
$67,5 \leq \bar{X}<82,5$ & Sedang \\
$52,5 \leq \bar{X}<67,5$ & Rendah \\
$30 \leq \bar{X}<52,5$ & Sangat Rendah \\
\hline
\end{tabular}

Berdasarkan Tabel 4 diperoleh kategori data kompetensi sikap sosial kelompok kontrol dan kelompok eksperimen yaitu termasuk dalam kategori sangat tinggi. Kategori tersebut dapat dilihat dari nilai rata-rata $\bar{X}$ kelompok eksperimen $=112,74$ dan $\bar{X}$ kelompok kotrol = 107,48.

Selanjutnya dilakukan pengujian hipotesis menggunakan uji-t yang terlebih dahulu dilakukan uji pasyarat diantaranya uji normalias sebaran data (uji Kolmogorov-Smirnov) dan uji homogenitas (uji F).

Berdasarkan hasil uji normalitas kelompok eksperimen, diperoleh nilai maksimum $\left|\mathrm{F}_{\mathrm{T}}-\mathrm{F}_{\mathrm{S}}\right|$ kelompok eksperimen $=0,126$ dan nilai tabel Kolmogorov-Smirnov untuk taraf signifikansi $5 \%(\alpha=0,05)=$ 0,215 karena nilai maksimum $\left|\mathrm{F}_{\mathrm{T}}-\mathrm{F}_{\mathrm{S}}\right|<$ nilai tabel Kolmogorov-Smirnov maka data berdistribusi 
normal. Berdasarkan hasil uji normalitas kelompok kontrol, diperoleh nilai maksimum $\left|F_{T}-F_{S}\right|$ kelompok kontrol $=0,148$ dan nilai tabel Kolmogorov-Smirnov untuk taraf signifikansi $5 \%(\alpha=0,05)=$ 0,231 karena nilai maksimum $\left|\mathrm{F}_{\mathrm{T}}-\mathrm{F}_{\mathrm{S}}\right|<$ nilai tabel Kolmogorov-Smirnov maka data berdistribusi normal.

Selanjutnya dilakukan uji homogenitas variansi dengan menggunakan uji F. Berdasarkan hasil uji homogenitas variansi kedua kelompok, diperoleh $\mathrm{F}_{\text {hitung }}=1,40$ dan $\mathrm{F}_{\text {tabel }}=1$,76. Dengan taraf signifikansi $5 \%(\alpha=0,05)$ dengan derajat kebebasan pembilang 33-1=32 dan derajat kebebasan penyebut 38-1 =37. Maka nilai $F_{\text {hitung }}=1,40<F_{\text {tabel }}=1,76$ yang disimpulkan bahwa data kedua kelompok memiliki variansi yang homogen.

Berdasarkan hasil uji prasyarat yang telah dilakukan, dapat disimpulkan bahwa data kedua kelompok sampel berdistribusi normal dan memiliki varians yang homogen. Dengan demikian, uji hipotesis menggunakan uji-t dapat dilakukan. Hipotesis yang diuji dalam penelitian ini adalah $\mathrm{H}_{0}$ yang berbunyi tidak terdapat perbedaan yang signifikan kompetensi sikap sosial antara kelompok siswa yang mengikuti pembelajaran dengan menerapkan pendekatan CTL berbantuan satua Bali dan kelompok siswa yang mengikuti pembelajaran dengan menerapkan pembelajaran konvensional pada kelas III SDN Gugus Kolonel I Gusti Ngurah Rai Kecamatan Denpasar Utara Tahun Pelajaran 2018/2019. Berikut disajikan rekapitulasi hasil uji hipotesis dengan menggunakan uji-t pada Tabel 3.

Tabel 3. Rekapitulasi hasil uji -t

\begin{tabular}{|c|c|c|c|c|c|c|c|}
\hline $\begin{array}{c}\text { Kelompok } \\
\text { Sampel }\end{array}$ & & $\mathbf{N}$ & dk & Variansi & $\bar{X}$ & $t_{\text {hitung }}$ & $t_{\text {tabel }}$ \\
\hline Eksperimen & 38 & \multirow{2}{*}{69} & & 25,44 & 112,74 & \multirow{2}{*}{4,024} & \multirow{2}{*}{2,000} \\
\hline Kontrol & 33 & & & 35,70 & 107,48 & & \\
\hline
\end{tabular}

Berdasarkan hasil uji hipotesis dengan uji-t, diperoleh thitung $=4,024$ dan untuk taraf signifikansi $5 \%$ dengan $\mathrm{dk}=(38+33-2)=69$ diperoleh ttabel $=2,000$. Dengan demikian thitung $=4,024>t_{\text {tabel }}=2,000$ sehingga Ho yang berbunyi tidak terdapat perbedaan yang signifikan kompetensi sikap sosial antara kelompok siswa yang mengikuti pembelajaran dengan menerapkan pendekatan CTL berbantuan satua Bali dan kelompok siswa yang mengikuti pembelajaran dengan menerapkan pembelajaran konvensional pada kelas III SDN Gugus Kolonel I Gusti Ngurah Rai Kecamatan Denpasar Utara Tahun Pelajaran 2018/2019. Dengan kata lain hasil penelitian yang dilakukan dapat disimpulkan bahwa pendekatan CTL berbantuan satua Bali memiliki pengaruh yang signifikan terhadap variabel terikat yaitu kompetensi sikap sosial siswa kelas III SDN Gugus Kolonel I Gusti Ngurah Rai Kecamatan Denpasar Utara Tahun Pelajaran $2018 / 2019$.

Berdasarkan hasil temuan tersebut, dapat dinyatakan kedua kelompok sampel penelitian yang memiliki kemampuan setara, setelah diberikan perlakuan berupa pembelajaran dengan menggunakan pendekatan CTL berbantuan satua Bali dan mengikuti pembelajaran konvensional diperoleh hasil kompetensi sikap sosial yang berbeda. Hal tersebut juga dapat dilihat dari rata-rata hasil kuesioner yang menunjukkan $\bar{X}$ kelompok eksperimen $>\bar{X}$ kelompok kontrol. Perbedaan tersebut disebabkan oleh perlakuan yang diberikan pada kelompok eksperimen berupa pendekatan $C T L$ berbantuan satua Bali.

Pada kelompok eksperimen, kegiatan pembelajaran diterapkan menggunakan pendekatan CTL berbantuan satua Bali. Kegiatan pembelajaran ini berjalan secara optimal karena menerapkan tujuh komponen yaitu konstruktivisme, inkuiri, bertanya, pemodelan, masyarakat belajar, penilaian autentik, dan refleksi serta dipadukan dengan satua Bali di setiap proses pembelajaran. Pendekatan CTL merupakan suatu inovasi pembelajaran yang menekankan siswa dalam pembentukan sikap sosial yang baik. Trianto (2015) menyatakan bahwa pendekatan CTL berbeda dengan pendekatan lainnya, sehingga memiliki karakteristik khusus yakni, kerja sama, saling menunjang, menyenangkan (joyfull), tidak membosankan (comfortable), belajar dengan bergairah, pembelajaran terintegrasi, memakai berbagai sumber, siswa aktif. Selain itu, (Hidayatin, 2016) menyatakan, pendekatan kontekstual memberikan arti dan manfaat khususnya bagi siswa diantaranya, dapat meningkatkan motivasi belajar siswa dalam memecahkan masalah serta mendapat pengalaman belajar yang dapat digunakan untuk menyelesaikan permasalahan.

Di awal perlakuan tidak semua siswa mampu mengaitkan pengetahuan yang dimiliki dengan pengalaman yang didapat, selain itu sedikit siswa yang mampu mengontrol kesabaran untuk berargumen pada saat penerapan komponen bertanya, serta tidak semua siswa memiliki rasa percaya diri ketika ditugaskan untuk menjelaskan hasil jawaban didepan kelas. Hal ini dikarenakan siswa belum terbiasa dengan kegiatan pembelajaran tersebut. Namun pada perlakuan kedua dan seterusnya siswa mulai 
terbiasa dengan kegiatan pembelajaran yang menggunakan pendekatan CTL berbantuan satua Bali. Hal ini tidak terlepas dari kelebihan dari pendekatan CTL menurut (Sanjaya, 2010) yaitu pembelajaran CTL menekankan kepada proses keterlibatan siswa secara penuh untuk menemukan materi yang dipelajari dan menghubungkan dalam kehidupan sehari-hari, pembelajaran di dalam kelas dapat berlangsung secara alamiah, alam pembelajaran CTL siswa dapat belajar melalui kegiatan kelompok, pembelajaran dikaitkan dengan kehidupan nyata, dalam pembelajaran CTL kemampuan didasarkan atas pengalaman, dalam pembelajaran CTL tindakan atau perilaku dibangun atas kesadaran diri sendiri, dalam pembelajaran CTL pengetahuan yang dimiliki setiap individu selalu berkembang sesuai dengan pengalaman yang dialaminya, tujuan akhir dari proses CTL adalah kepuasan diri.

Selama kegiatan pembelajaran, siswa dapat menemukan contoh sikap sosial yang baik melalui satua Bali yang diceritakan oleh guru dan dijadikan pedoman oleh siswa dalam berperilaku. Beberapa satua Bali dipilih sesuai tema pembelajaran dan kehidupan sehari-hari. Contoh sikap sosial yang didapatkan siswa melalui satua Bali diterapkan secara langsung pada kegiatan pembelajaran yang meliputi tujuh komponen pendekatan CTL. Satua dalam bahasa Indonesia dikenal dengan cerita. Bercerita merupakan salah satu contoh komunikasi yang efektif untuk mengubah sikap, karena unsur-unsur sikap dapat diselipkan dalam bersatua. Merubah atau membentuk sikap dilakukan juga oleh salah satu ahli yaitu Skinner dalam teorinya operant conditioning. Teori tersebut menekankan pada proses peneguhan respon anak. (I Gusti Kade Budi Astawa, Putu Nanci Riastini, 2016), menyatakan, satua Bali memiliki nilai budaya, nilai karakter, dan amanat sehingga pembelajaran yang berlangsung menjadi lebih menarik, menyenangkan, dan bermanfaat bagi pengembangan sikap sosial siswa. Selain itu, (A.A.Istri Vera Mahayuni, Nym. Kusmariyatni, 2015)berpendapat bahwa, manfaat cerita bagi anak adalah membantu pembentukan pribadi dan moral anak, menyalurkan kebutuhan imajinasi dan fantasi, memacu kemampuan verbal anak, merangsang minat menulis anak, merangsang minat baca anak, dan membuka cakrawala pengetahuan anak. Tradisi bercerita dalam budaya kehidupan masyarakat di Bali banyak digunakan untuk menyampaikan nasehat atau saran tentang perilaku khususnya dikalangan anak-anak (Wirata, 2016). Bercerita dapat dilakukan dimana saja, dan Sekolah Dasar dianggap sebagai tempat yang paling tepat untuk melestarikan tradisi mesatua.

Namun pada awal perlakuan, beberapa siswa kurang memahami tentang satua Bali. Untuk mengatasi hal tersebut, maka guru menceritakan satua Bali menggunakan bahasa Indonesia tetapi tidak mengurangi makna dari satua Bali tersebut. Selama kegiatan pembelajaran, siswa lebih merasa percaya diri, dapat mengontrol kesabaran, tumbuh rasa tanggung jawab, dan menumbuhkan sikap sosial yang baik lainnya karena kegiatan pembelajaran dikemas dengan komponen pembelajaran yang bervariasi dan menyenangkan. Selain itu, siswa juga diberi kebebasan untuk memilah perilaku sesuai dengan contoh sikap sosial yang telah didapatkan.

Hasil temuan pada penelitian ini memiliki persamaan dengan penelitian sebelumnya yang relevan, dan memperkuat hasil penelitian yang diperoleh. Hal tersebut didukung oleh penelitian yang relevan, yakni penelitian yang dilakukan oleh (Suwarni, 2011) pada siswa kelas III MI Podorejo Tulungagung dengan meneliti pendekatan CTL terhadap motivasi dan hasil belajar siswa kelas III yang memiliki pengaruh signifikan. Selain itu penggunaan satua Bali juga didukung dari penelitian yang dilakukan oleh (A.A.Istri Vera Mahayuni, Nym. Kusmariyatni, 2015)pada siswa kelas IV, dengan meneliti pengaruh media satua Bali terhadap minat belajar IPA siswa kelas IV yang berpengaruh signifikan. Namun pada penelitian ini meneliti tentang pengaruh pendekatan CTL berbantuan satua Bali terhadap kompetensi sikap sosial siswa kelas III. Dengan demikian, pembelajaran menggunakan pendekatan CTL berbantuan satua Bali pada penelitian ini memiliki keunggulan yakni dapat membentuk sikap sosial siswa yang baik, mengoptimalkan penggunaan pendekatan pembelajaran yang lebih inovasi, dan pelestarian penggunaan satua Bali yang kian ditinggalkan.

\section{Simpulan dan Saran}

Berdasarkan perhitungan, uji hipotesis dan pembahasan hasil penelitian, diperoleh hasil thitung $=$ 4,024 , sedangkan tabel $=2,000$ pada taraf signifikansi $5 \%$ dengan $\mathrm{dk}=69$. Karena harga $\mathrm{t}_{\text {hitung }}=4,024>$ $t_{\text {tabel }}=2,000$, maka $\mathrm{H}_{\mathrm{o}}$ ditolak (gagal diterima). Hasil ini menunjukkan bahwa terdapat perbedaan yang signifikan kompetensi sikap sosial antara kelompok eksperimen dan kelompok kontrol. Sehingga dapat disimpulkan pendekatan CTL berbantuan satua Bali memiliki pengaruh yang signifikan terhadap kompetensi sikap sosial siswa kelas III SDN Gugus Kolonel I Gusti Ngurah Rai Kecamatan Denpasar Utara Tahun Pelajaran 2018/2019.

Berdasarkan simpulan tersebut adapun saran yang dapat disampaikan yaitu, kepada guru disarankan agar guru mencoba menerapkan pendekatan CTL berbantuan satua Bali secara lebih lanjut untuk dapat mengoptimalkan kompetensi sikap sosial siswa, kepada kepala sekolah agar 
merekomendasikan pendekatan CTL berbantuan satua Bali terhadap para guru yang ada di sekolahnya agar menjadikan sebagai alternatif perbaikan kualitas pembelajaran khususnya dalam pembentukan sikap sosial, kepada peneliti lain disarankan untuk menggunakan hasil penelitian ini sebagai acuan dalam melakukan penelitian selanjutnya untuk memperoleh hasil yang lebih baik.

\section{Daftar Rujukan}

A.A.Istri Vera Mahayuni, Nym. Kusmariyatni, P. N. R. (2015). Pengaruh Media Satua Bali Terhadap Minat Belajar Ipa Siswa Kelas Iv Sd Di Gugus II. E-Journal PGSD Universitas Pendidikan Ganesha, 3(1).

Abdullah. (2017). Pendekatan dan Model Pembelajaran yang Mengaktifkan Siswa. Jurnal Pendidikan dan pembelajaran. ejournal.unuja.ac.id

Abu Ahmadi. (2009). Psikologi Umum. Rineka Cipta.

Agung, A. A. G. (2014). Metodologi Penelitian Pendidikan. Aditya Media Publish.

Christin Septina Basani. (2015). Kurikulum Nasional Yang Berbasis Kompetensi Perguruan Tinggi Dengan Mengacu Pada Kerangka Kualifikasi Nasional Indonesia (KKNI) Untuk Menghasilkan Kualitas Manusia Yang Kompeten Dan Berdaya Saing. MAranatha. https://journal.maranatha.edu/index.php/dialogia/article/view/709/705

Hidayatin, N. (2016). Pengaruh Pendekatan Contextual Teaching and Learning (Ctl) Terhadap Hasil Belajar Matematika. Buana Matematika : Jurnal Ilmiah Matematika Dan Pendidikan Matematika, 6(1:), 49-56. https://doi.org/10.36456/buanamatematika.v6i1::377

I Gusti Kade Budi Astawa, Putu Nanci Riastini, N. N. G. (2016). Pengaruh Model Pembelajaran Role Playing Berbantuan Satua Bali Terhadap Sikap Sosial Dan Pemahaman Konsep Siswa. E-Journal PGSD Universitas Pendidikan Ganesha, 4(1), 1-11.

Nurlaela, A. (2016). Peranan Lingkungan Sebagai Sumber Pembelajaran Geografi Dalam Menumbuhkan Sikap Dan Perilaku Keruangan Peserta Didik. Jurnal Geografi Gea, 14(1), 40-48. https://doi.org/10.17509/gea.v14i1.3361

Sadirman. (2014). . Interaksi dan Motivasi Belajar Mengajar. Rajawali Pers.

Sanjaya, W. (2010). Strategi Pembelajaran Berorientasi Standar Proses Pendidikan. In 1. Prenada Media Group.

Suwarni. (2011). Pengaruh Gaya Kepemimpinan Kepala Sekolah dan Budaya Sekolah terhadap Kinerja Guru. Jurnal Pendidikan Dan Pembelajaran, 18(2).

Wahyuni, H. T., Setyosari, P., \& Kuswandi, D. (2016). Implementasi Pembelajaran Tematik Kelas 1 Sd. Edcomtech, 1(2), 129-136.

Wirata, D. (2016). Pengaruh Tradisi Bercerta Sebagai Metode Pendekatan KelompokTeman Sebaya Dalam Upaya Merubah Perilaku Menyikat Gigi Siswa SDN 5 Sayan Ubud Gianyar Tahun 2016.

Yusuf, M. (2015). Asesmen Dan Evaluasi Pendidikan Pilar Penyedia Informasi dan Kegiatan Pengendalian Mutu Pendidikan. In 1. Prenadamedia Group. 